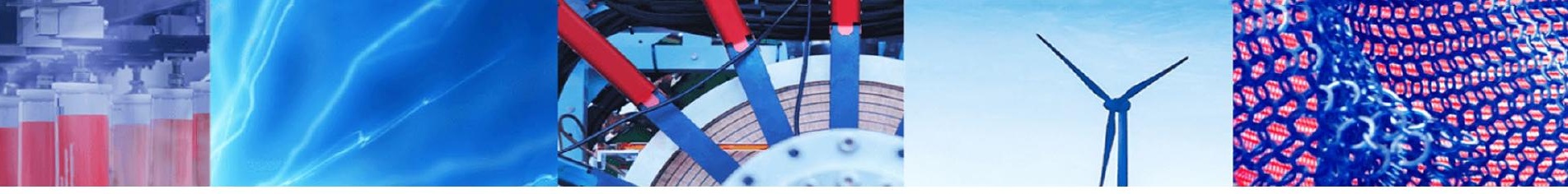

Research Article

\title{
Recycling of tellurium via copper smelting processes
}

\author{
Lassi Klemettinen $^{1}$ (1) $\cdot$ Katri Avarmaa $^{1} \cdot$ Dmitry Sukhomlinov $^{1,2} \cdot$ Hugh O'Brien $^{3} \cdot$ Pekka Taskinen $^{1} \cdot$ Ari Jokilaakso $^{1}$
}

Received: 19 July 2019 / Accepted: 30 January 2020 / Published online: 4 February 2020

(c) The Author(s) 2020 OPEN

\begin{abstract}
The modern world continuously demands more raw materials for manufacturing all kinds of products. Nowadays, the lifetime of a single product can be very short, as is the case with electronic appliances. Waste electrical and electronic equipment (WEEE) is one of the fastest growing waste categories, and one of the most promising recycling routes for WEEE is to use it as a feed material in pyrometallurgical copper smelting. This article presents new experimental observations regarding the behavior of tellurium in secondary copper smelting process, and compares the results to primary smelting experiments. In secondary smelting conditions, most of tellurium distributed into the copper phase, and the distribution coefficient between copper and slag decreased with increasing oxygen partial pressure. In the primary smelting experiments, most of tellurium was vaporized into flue dusts, and the distribution coefficient between copper matte and slag increased with increasing oxygen pressure, i.e. increasing matte grade.
\end{abstract}

Keywords Copper · Trace element · Slag · Distribution · WEEE

\section{Introduction}

Various copper smelting processes are efficient and widely used ways of treating different kinds of copper-bearing wastes, such as waste electrical and electronic equipment (WEEE). With the reducing grade of primary copper ores and the increasing amount and complexity of electronic scrap, new elements are introduced into the smelting circuits. For the most efficient recovery of these elements, and finding optimal process parameters, fundamental knowledge about the behavior of different elements is required. This article presents experimental results on the distribution of tellurium between copper and slag in simulated laboratory-scale secondary copper smelting conditions. In addition to the iron silicate base slag, alumina and potassium oxide were introduced in the slag to investigate their effect on the process, i.e. slag composition and trace element behavior. In industrial operations, alumina originates from WEEE as well as the sand used for fluxing. This sand may, depending on the location, also contain up to $5 \mathrm{wt} \%$ potassium oxide, the effects of which are not well known.

Tellurium is found in primary copper ores, and most of the tellurium produced in the world comes from processing of copper anode slime, which is a by-product formed during electrolytic refining of copper. Traditionally, tellurium has been mostly used as an additive in copper, iron, steel and lead alloys [1,2]. In recent years, the demand of tellurium has increased significantly due to the large-scale production of $\mathrm{CdTe}$ photovoltaic panels, where approximately $40 \%$ of the tellurium produced annually is currently used $[2,3]$. The amount of tellurium in one photovoltaic panel is low, around $0.1 \%$ of the total mass of the panel [4]. However, as the demand for solar energy increases and

$\triangle$ Lassi Klemettinen, lassi.klemettinen@aalto.fi; Katri Avarmaa, katri.avarmaa@aalto.fi; Dmitry Sukhomlinov, dmitry.sukhomlinov@ ntnu.no; Hugh O'Brien, hugh.obrien@gtk.fi; Pekka Taskinen, pekka.taskinen@aalto.fi; Ari Jokilaakso, ari.jokilaakso@aalto.fi | Department of Chemical and Metallurgical Engineering, Aalto University, P.O. Box 16100, 02150 Espoo, Finland. ${ }^{2}$ Present Address: Department of Materials Science and Engineering, Norwegian University of Science and Technology, 7491 Trondheim, Norway. ${ }^{3}$ Geological Survey of Finland, Vuorimiehentie 2, 02150 Espoo, Finland. 
most likely CdTe thin film panels will continue to be one of the main technologies in the near future, recycling of the tellurium values should be improved [4-6]. Tellurium, in different forms, is currently also used in thermoelectric devices, semiconductors, optical disks, phase change memory chips, glass optical fibres and as a vulcanizing agent $[1,3,6]$.

Regarding the future uses of tellurium, several articles dealing with new chemistries for providing alternatives to lithium-ion batteries have been published recently. Zhang et al. [7] investigated tellurium-aluminium batteries, $\mathrm{Li}$ et al. [8] studied liquid metal batteries with tellurium-tin based electrodes, Koketsu et al. [9] and Li et al. [10] published research about lithium-tellurium batteries, just to name a few. These technologies are still years away from being in commercial use; nevertheless, it is important to establish the most efficient recycling processes before the End-of-Life (EoL) products are entering the recycling and material recovery stage.

Some previous studies have been conducted regarding the behavior of tellurium in different geological/metallurgical systems. Brenan [11] conducted high-pressure studies on the distribution of tellurium between molten and solid sulfides and silicates at $1200-1300^{\circ} \mathrm{C}$. He found that the distribution coefficient is strongly dependent on the $\mathrm{FeO}$ concentration in the silicate. Avarmaa et al. [12] studied the behavior of tellurium in Doré smelting, i.e. between metallic silver and different types of $\mathrm{SiO}_{2}-\mathrm{Na}_{2} \mathrm{O}$ slags at $1000-1300^{\circ} \mathrm{C}$. Swinbourne et al. [13] investigated the distribution of tellurium in a similar system consisting of silver-copper selenide matte and $\mathrm{SiO}_{2}-\mathrm{Na}_{2} \mathrm{O}$ slag.

Johnson et al. [14, 15] studied the distribution of tellurium between copper matte and iron silicate slags at $1250^{\circ} \mathrm{C}$. They did not report distribution coefficients, only the equilibrium solubilities of tellurium into the slags due to tellurium-saturation of the experimental system, which lead to inconsistent Te concentrations in the matte phase. However, their conclusion was that slag additives $\mathrm{Al}_{2} \mathrm{O}_{3}$, $\mathrm{CaO}$ and $\mathrm{MgO}$ had a negligible effect on the behavior of tellurium. Choi and Cho [16] determined the distribution coefficient of Te between nickel-copper matte and iron silicate slags. They did not control the partial pressure of sulfur, only the partial pressure of oxygen in the system. Johnston et al. [17] investigated the effect of slag basicity on the behavior of tellurium in metallic copper-magnesia saturated calcium iron silicate slag systems, and noticed a non-linear dependency between the distribution coefficient and slag basicity. Kojo et al. [18] studied the thermodynamics of tellurium removal from copper by using sodium carbonate slags, and found a maximum in the distribution coefficient of tellurium at approximately $10^{-2} \mathrm{~Pa}$ oxygen partial pressure. Schlitt and Richards [19] measured the distribution coefficient of tellurium between copper matte and metallic copper, and found that tellurium was preferentially distributed into the matte phase, where the concentration was approximately sevenfold compared to the metal phase, independently of the iron concentration in matte and the prevailing oxygen partial pressure. The behavior of several trace elements, including tellurium, in copper smelting conditions have also been modelled to some extent $[20,21]$.

In this article, the distribution behavior of tellurium between metallic copper and three types of iron silicate slags at iron-alumina spinel saturation was investigated and compared to data obtained from earlier studies. The results indicated a completely different behavior for tellurium in primary and secondary copper smelting processes. The influence of potassium oxide addition into the slag was discussed with the help of constrained quasiternary phase diagrams constructed with the MTOX database [22].

\section{Experimental}

The experiments were conducted in a vertical tube furnace Nabertherm RHTV 120-150/18 (Nabertherm, Germany). The experimental temperature, set to $1300^{\circ} \mathrm{C}$ for every experiment, was monitored throughout the experiments with a calibrated Pt/Pt10Rh thermocouple connected to a Keithley 2010 DMM multimeter (Keithley, USA), and the cold junction temperature was measured with a Pt100 resistance thermometer connected to a Keithley 2000 DMM multimeter. The desired gas atmospheres were obtained using a $\mathrm{CO}-\mathrm{CO}_{2}$ gas mixture. The most important experimental parameters have been collected in Table 1. A more detailed description of the experimental set-up has been presented earlier [23].

The starting metal and oxide (slag) mixtures were prepared from pure powders. The copper metal mixture was mixed of copper (99.999\%, Alfa Aesar) and trace elements $\mathrm{Ni}$ (99.996\%, Alfa Aesar), Sn (99.85\%, Alfa Aesar), Sb (99.9\%, Alfa Aesar) and Te (99.99\%, Alfa Aesar), all 1 wt\% of the mass of copper. The slag, with an initial $\mathrm{Fe} / \mathrm{SiO}_{2}$ ratio of 1.3, was mixed of $\mathrm{SiO}_{2}$ (99.99\%, Umicore) and $\mathrm{Fe}_{2} \mathrm{O}_{3}$ (99.99\%, Alfa Aesar). Additions of approximately 3 and 5 wt\% of $\mathrm{K}_{2} \mathrm{O}$ (initially as $\mathrm{K}_{2} \mathrm{CO}_{3}, 99.5 \%$, Sigma-Aldrich) were used for investigating the effect of basic oxides on the distribution coefficient of tellurium, as well as the slag boundaries of the equilibrium system. The parameters for the primary copper smelting experiments, the results of which have been compared to the secondary smelting results in the Sect. 3, have been presented in another article [24].

The total sample mass was approximately 0.4 grams and equilibrations were performed in small cylindershaped alumina crucibles ( $>99.5 \% \mathrm{Al}_{2} \mathrm{O}_{3}$, Degussit AL23, Friatec NA, Germany; ID $8 \mathrm{~mm}$ and $\mathrm{H} 15 \mathrm{~mm}$ ). The 
Table 1 Experimental parameters as well as EPMA and LA-ICP-MS detection limits in copper alloy and slag

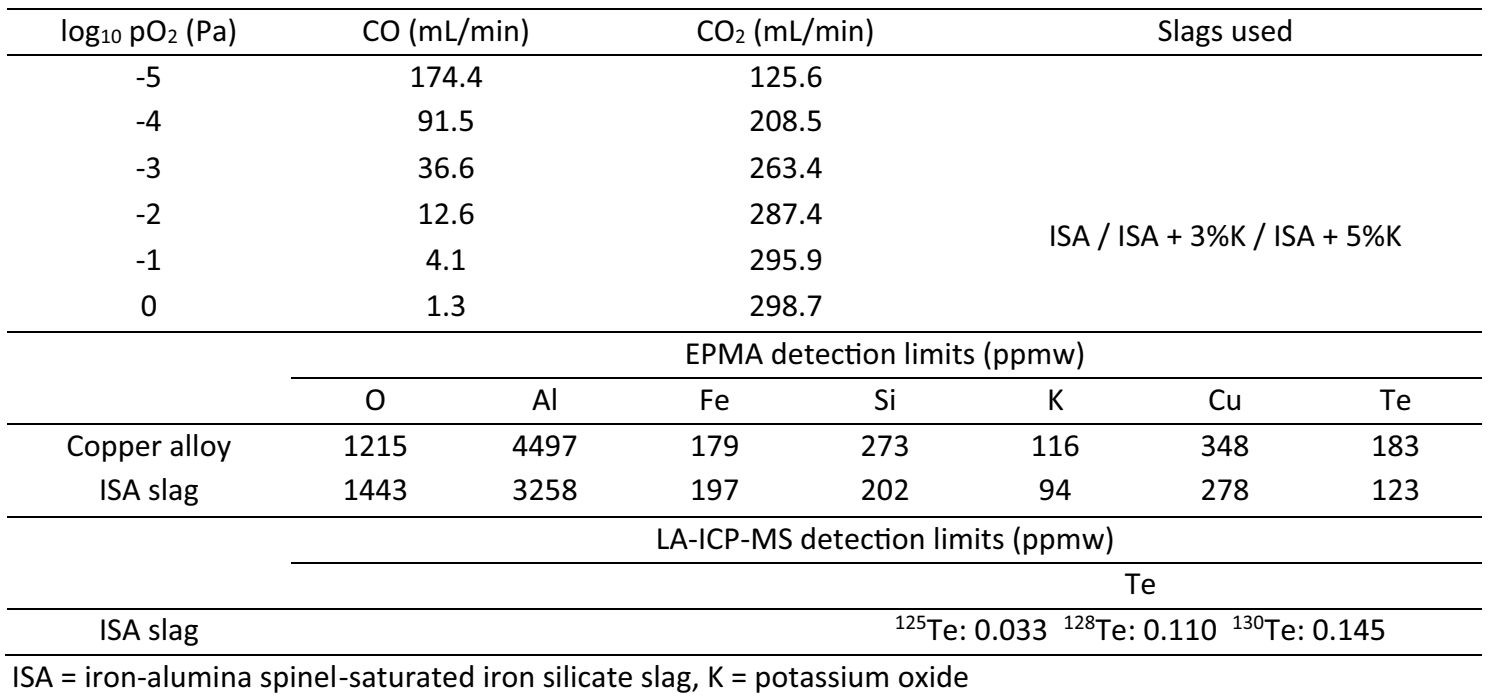

distribution behavior of nickel, tin and antimony in the system have been presented in our previous publications $[23,25]$. After equilibration, the quenched samples were cast in epoxy resin, followed by grinding, polishing and carbon coating. The microstructures and phase homogeneity were analyzed with SEM-EDS (scanning electron microscope: LEO 1450, Carl Zeiss AG, Germany-energy dispersive spectrometer: X-Max $50 \mathrm{~mm}^{2}$, Oxford Instruments, UK). Based on the phase composition results from EDS, shown in "Appendix", $16 \mathrm{~h}$ was deduced to be a sufficient equilibration time for the copper-slag system. Duplicate experiments were conducted for the $\mathrm{K}_{2} \mathrm{O}$-free and $3 \mathrm{wt} \% \mathrm{~K}_{2} \mathrm{O}$-containing samples to ensure the reliability and reproducibility of the results.

The elemental compositions of each phase in the equilibrated samples were analyzed directly with EPMA (electron probe microanalysis: SX-100 equipped with five wavelength dispersive spectrometers, Cameca SAS, France). Eight analysis points were taken from each phase. A defocused, 50-100 $\mu \mathrm{m}$ electron beam was used for the copper alloy and slag phases. The accelerating voltage was $20 \mathrm{kV}$ and the beam current $60 \mathrm{nA}$ in every analysis point. The employed standards and analyzed $\mathrm{X}$-ray lines were hematite $(\mathrm{O} \mathrm{Ka}$ and $\mathrm{Fe} \mathrm{Ka})$, quartz (Si Ka), sanidine (K Ka), alumina ( $\mathrm{Al} K \beta)$, copper (Cu Ka) and antimony telluride (Te La). PAP-ZAF matrix correction [26] was used for raw data processing. The totals of the individual analysis points were between 98 and $100 \mathrm{wt} \%$. The detection limits of each element have been collected in Table 1.

The concentrations of tellurium in slags were below the detection limits of EPMA, and therefore the slags were analyzed with LA-ICP-MS (laser ablation-inductively coupled plasma-mass spectrometry) as well. A Photon Machines Analyte Excite 193 nm ArF laser ablation device (Teledyne CETAC Technologies, USA) coupled to a Nu Attom SC-ICP-MS (Nu Instruments Ltd, UK) was used. The laser spot size was set to $85 \mu \mathrm{m}$ and laser energy adjusted to $30 \%$ of $5.0 \mathrm{~mJ}$, resulting in a fluence of $2.5 \mathrm{~J} / \mathrm{cm}^{2}$ on the surface of the samples. The laser was fired at a $10 \mathrm{~Hz}$ frequency with each pulse lasting $4 \mathrm{~ns}$. The mass spectrometer was operated in FastScan mode using low resolution $(M / \Delta M=300)$ to maximize sensitivity. Eight pits were ablated from the slag phase of each sample.

NIST 612 standard reference material [27] was used as the external, and $\mathrm{Si}$ (measured with ${ }^{29} \mathrm{Si}$ in the MS) as the internal standard, respectively. NIST 610 as well as BHVO-2G and BCR-2G basaltic glasses were analyzed as unknowns. The Glitter software package [28] was applied for processing the obtained time-resolved analysis (TRA) signals. The concentrations of tellurium in slags were calculated as averages of three isotopes, see Table 1.

\section{Results and discussion}

\subsection{Microstructure and phase compositions}

Figure 1 illustrates a typical microstructure of the equilibrated-quenched sample. The equilibrium assembly consisted of three phases: copper alloy, slag and ironaluminous spinel. In reducing conditions, the spinel only formed on the interface of the crucible and slag, whereas in oxidizing conditions individual spinel grains were observed floating within the slag, as seen in Fig. 1. All the alumina dissolved in the slag and spinel originated from 


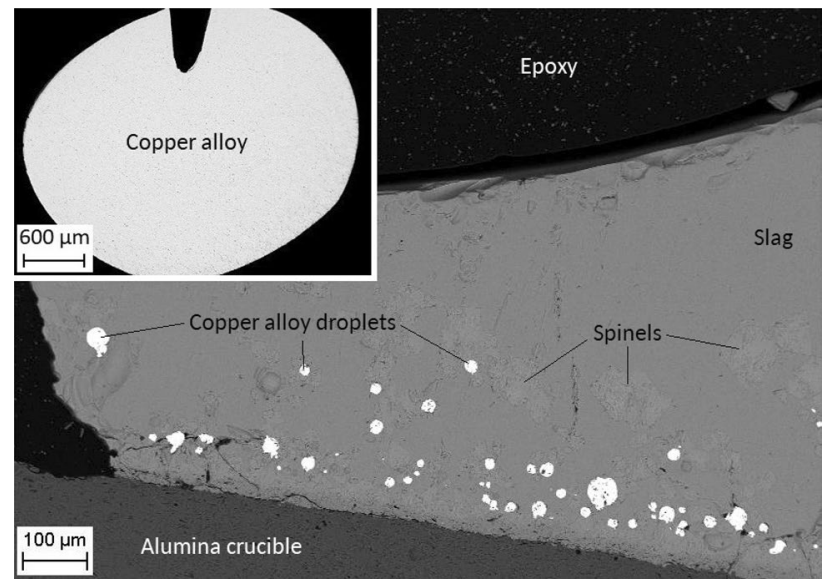

Fig. 1 SEM-BSE image of typical sample microstructure postquenching. Sample ISA $+5 \% \mathrm{~K}, \mathrm{pO}_{2} 10^{-3} \mathrm{~Pa}$

the alumina crucible. The formation and composition of the spinels have been discussed in detail previously [25].

The addition of potassium oxide in the iron-alumina spinel-saturated iron silicate slag increased the activity coefficients of iron oxides in the slag, therefore decreasing iron solubility in the slag and increasing the fraction of spinel in the system. This also resulted in increased solubility of silica in the slag, therefore lowering the $\mathrm{Fe} / \mathrm{SiO}_{2}$-ratio shown in Fig. 2. The trend lines follow the oxygen partial pressures very well; at $1 \mathrm{~Pa} \mathrm{pO}_{2}$, the $\mathrm{Fe} / \mathrm{SiO}_{2}$-ratio is the lowest and at $10^{-5} \mathrm{~Pa}$ the highest. At higher oxygen partial pressures, both the increased solubility of copper in slag and the change in spinel composition contributed to the further decrease in the $\mathrm{Fe} / \mathrm{SiO}_{2}$ ratio [25]. The alumina concentration in the slags, 17-19 wt\%, remained virtually unaffected by the changes in oxygen potential. More details of the composition of the slag, spinel and copper phases have been published earlier $[23,25]$.

\subsection{Phase diagram information}

Equilibrium phase diagrams representing the influence of potassium oxide on the $\mathrm{Al}_{2} \mathrm{O}_{3}-\mathrm{SiO}_{2}-\mathrm{FeO}_{\mathrm{x}}$ slag system were calculated employing MTDATA and MTOX database [22]. Figure 3 presents a constrained quasiternary phase diagram of the $50 \mathrm{wt} \% \mathrm{Al}_{2} \mathrm{O}_{3}-\mathrm{SiO}_{2}-\mathrm{FeO}_{\mathrm{x}}$ system without $\mathrm{K}_{2} \mathrm{O}$ (black lines and labels) and with $5 \mathrm{wt} \% \mathrm{~K}_{2} \mathrm{O}$ (pink lines) at $1573.15 \mathrm{~K}\left(1300^{\circ} \mathrm{C}\right)$ and $10^{-4} \mathrm{~Pa}$ oxygen partial pressure. Figure 4 shows the influence of copper saturation (Cu-sat: black lines and labels, $\mathrm{Cu}$-free: green lines) on the $\mathrm{Al}_{2} \mathrm{O}_{3}-\mathrm{SiO}_{2}-\mathrm{FeO}_{\mathrm{x}}-3 \mathrm{wt} \% \mathrm{~K}_{2} \mathrm{O}$ system at $1573.15 \mathrm{~K}$ and $0.1 \mathrm{~Pa}$ oxygen partial pressure. Copper dissolves increasingly into the slag as a function of increasing oxygen partial pressure, and thus a high $\mathrm{pO}_{2}$ with high equilibrium copper solubility was chosen for the calculations.

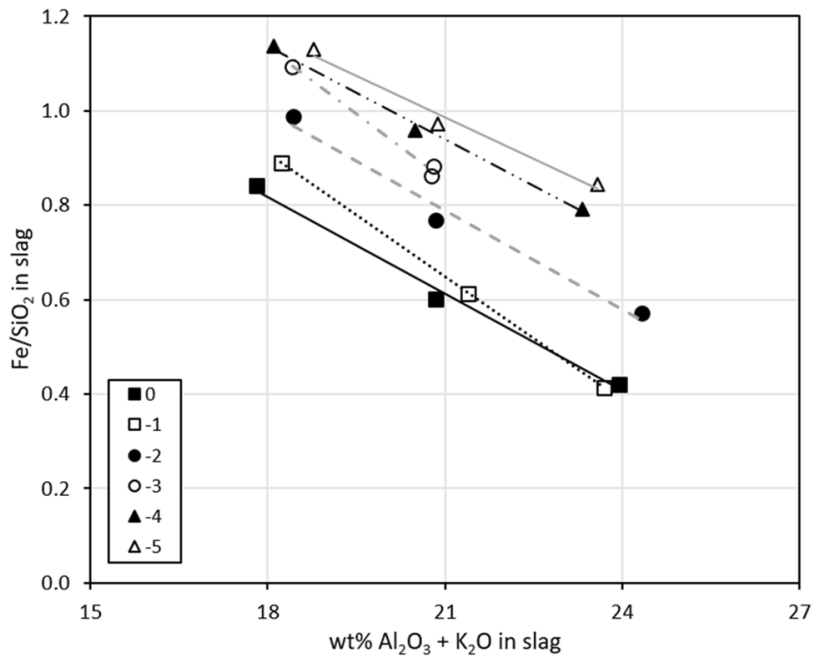

Fig. $2 \mathrm{Fe} / \mathrm{SiO}_{2}$ ratio in slags as a function of the cumulative amphoteric/basic oxide concentration. The experimental points on the left correspond to the slag with no $\mathrm{K}_{2} \mathrm{O}$, and the ones on the right to the slag with $5 \mathrm{wt} \% \mathrm{~K}_{2} \mathrm{O}$ addition, respectively. $\log _{10} \mathrm{pO}_{2}(\mathrm{~Pa})$ of each series is shown in the legend

As can be seen from the figures, potassium oxide addition increases the number and complexity of equilibrium phase assemblages, especially at the low silica range and towards the alumina apex. In Fig. 3, the tridymite-liquid boundary as well as the mullite-spinel double saturation point radically move towards the silica corner with $\mathrm{K}_{2} \mathrm{O}$ addition. When the dissolved copper is taken into consideration at high oxygen partial pressures (Fig. 4), the liquid domain is somewhat broadened by shifting the spinel-liquid phase boundary towards lower silica compositions. Our experimental results and phase diagram calculations show increasing silica concentration in slag as potassium oxide is included in the system, as well as when the oxygen partial pressure is decreased. Our experimental slag composition results are relatively close to the spinel-oxide liquid phase boundary of the calculated phase diagrams, although somewhat richer in silica. When compared to experimentally obtained results, it seems that the MTOX database exaggerates the equilibrium alumina solubility in the slag with and without $\mathrm{K}_{2} \mathrm{O}$ addition.

\subsection{Distribution behavior of tellurium}

Figure 5 illustrates the equilibrium concentrations of tellurium in copper alloy (Fig. 5a) and in spinel-saturated slag (Fig. 5b) in parts per million by weight (ppmw). The exact concentrations of tellurium in the spinel phase, which were below the detection limit of EPMA (120 ppmw) in all experimental conditions, were not analyzed with LAICP-MS due to the small size of the individual spinels. 
Fig. 3 Triangular section of $50 \mathrm{Al}_{2} \mathrm{O}_{3}-\mathrm{SiO}_{2}-\mathrm{FeO}_{\mathrm{x}}$ ternary system at $10^{-4} \mathrm{~Pa} \mathrm{pO}_{2}$. The phase boundaries with 0 (black lines) and $5 \mathrm{wt} \% \mathrm{~K}_{2} \mathrm{O}$ (pink lines) have been superimposed. OX_LIQ = slag, SPI = spinel, $\mathrm{TRI}=$ tridymite, $\mathrm{MUL}=$ mullite, $\mathrm{HAL}=$ halite, $\mathrm{G}=$ gas

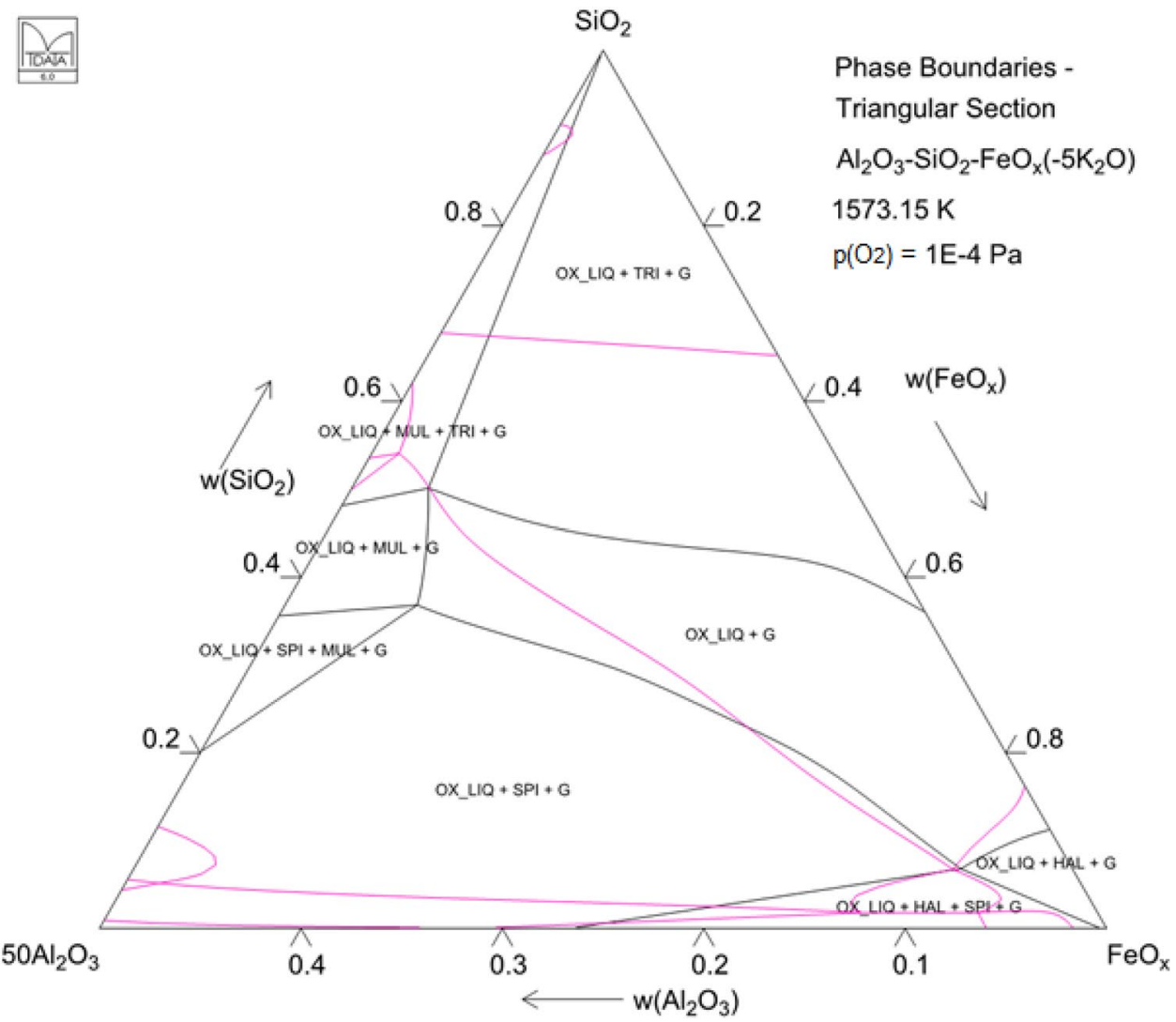

Fig. 4 Triangular section of $\mathrm{Al}_{2} \mathrm{O}_{3}-\mathrm{SiO}_{2}-\mathrm{FeO}_{\mathrm{x}}$ ternary system with $3 \mathrm{wt} \% \mathrm{~K}_{2} \mathrm{O}$ at $0.1 \mathrm{~Pa}$ oxygen partial pressure. The phase boundaries without copper (green lines) and at copper saturation (black lines) have been superimposed. $\mathrm{COR}=$ corundum, NEP $=$ nepheline, $\mathrm{LIQ}=$ copper (at Cu-saturation)

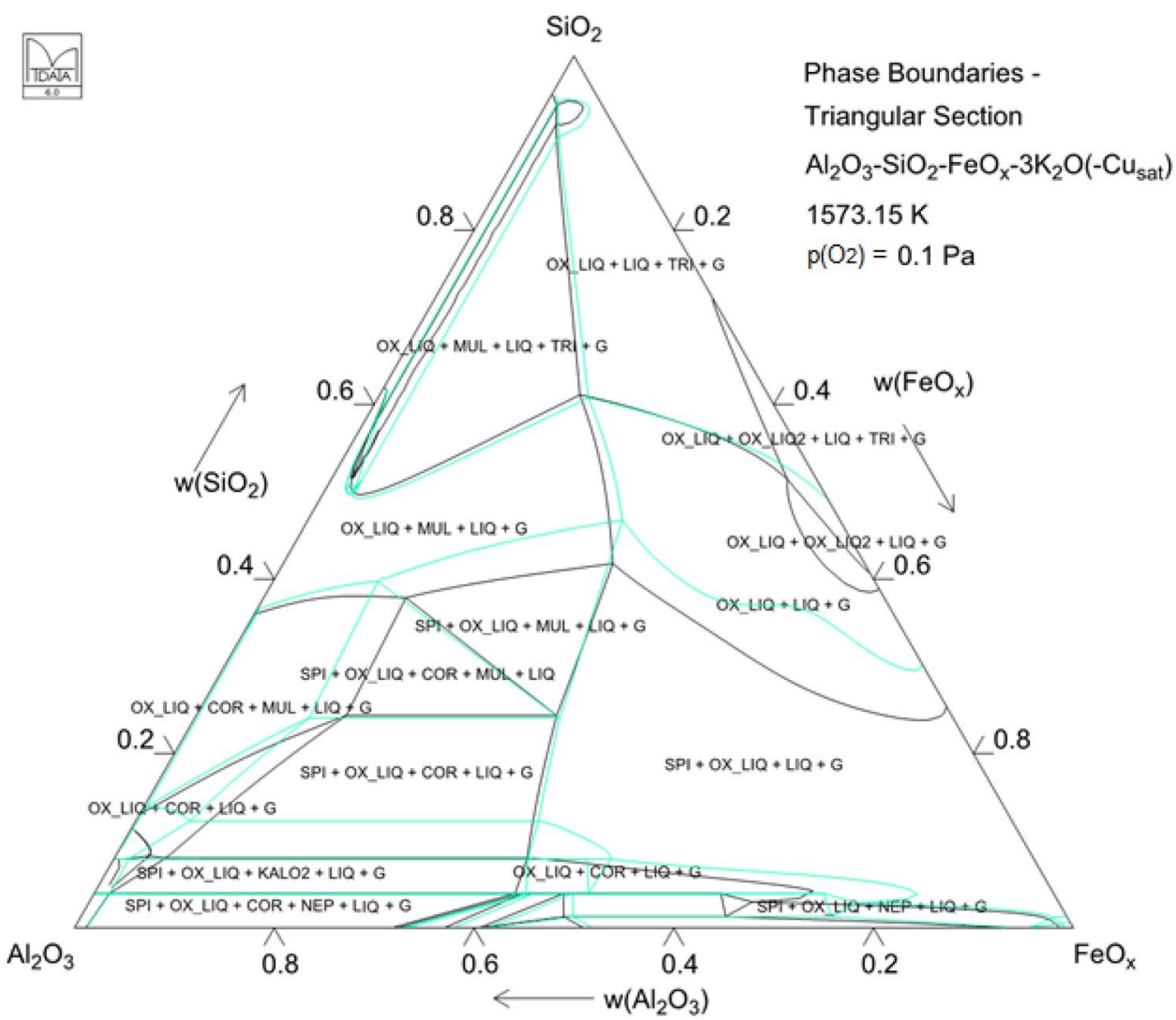

SN Applied Sciences 
Concentration values from matte-slag experiments [24] have also been plotted in Fig. 5 for comparison.

In the copper alloy-slag system, the addition of $\mathrm{K}_{2} \mathrm{O}$ increased the concentration of tellurium in the alloy in oxidizing conditions, and correspondingly slightly decreased the concentration in slag. In the matte-slag experiments, the addition of alumina and lime decreased the concentration of Te in matte, but had no clear effect on the concentrations in slags. The results in slags exhibited a large scatter, mostly due to the very low concentrations, which were often even below the detection limits of LA-ICP-MS. In the matte-slag system, by far most of the tellurium was vaporized into the gas phase, which is evident when combining the concentrations in matte and slag phases. The vaporization was far less significant in the secondary copper smelting experiments, i.e. the copper alloy-slag system. However, around $50 \%$ of tellurium was vaporized in these experiments (in reducing conditions) as well, as shown by the equilibrium concentrations in Fig. 5. The crucibles used in this study and by Sukhomlinov et al. [24] had different geometries, the latter possibly providing a better contact with the gas phase. However, the equilibration time in the present experiments was four times that used in the matte-slag equilibrations, thus eliminating the possible effects of the crucible geometry on the volatilization of tellurium.

Many researchers have stated that the vaporization of tellurium in copper matte smelting conditions is not significant, and tellurium cannot be removed either by slagging or vaporization due to its high stability in matte $[19,20]$. This conclusion does not agree with the experimental observations of Sukhomlinov et al. [24] or the tellurium-sulfur phase diagram, which suggests formation of

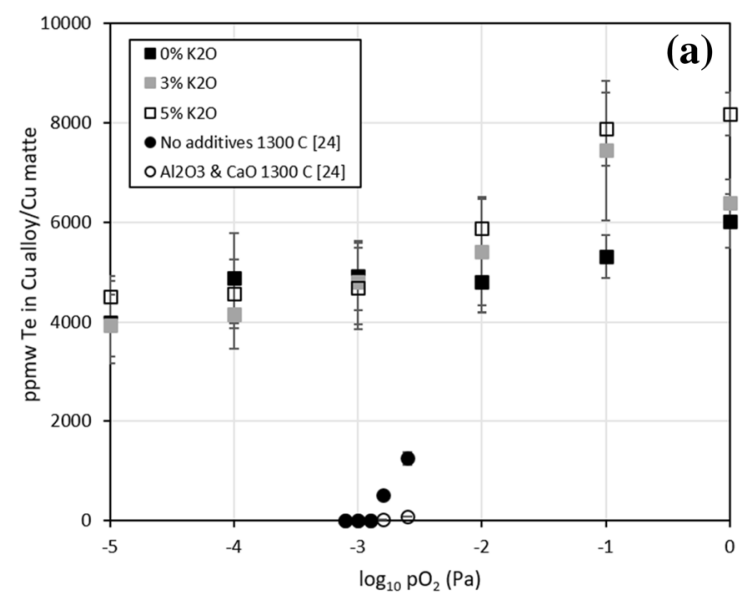

Fig. 5 a Equilibrium concentration of tellurium in copper alloy. $\mathbf{b}$ Equilibrium concentration of tellurium in slags. Both shown as a function of oxygen partial pressure. In both figures, the concen- a tellurium-containing sulfide gas phase at copper matte smelting temperatures [29].

In the copper alloy-slag results obtained in our study, vaporization of tellurium seems to be more significant in reducing conditions, i.e. at low oxygen partial pressures, than in oxidizing conditions. An evident explanation for this is the behavior of oxygen as a surface active element: it enriches on the surface of copper alloy, thus preventing tellurium from evaporating [30]. The surface active property of oxygen in copper, as a function of oxygen partial pressure, is a well-documented feature in the literature, e.g. by Gallois and Lupis [31] and Nexhip et al. [32]. Hino and Itagaki [33] reported activity coefficients of tellurium in copper alloys and the low values obtained (approximately $6.5 \times 10^{-2}$ at $1200^{\circ} \mathrm{C}$ ) also suggest that volatilization of tellurium from liquid copper is not very significant.

The distribution coefficient $L$ of tellurium between copper and slag was calculated simply according to Eq. (1). The obtained values have been plotted in logarithmic form in Fig. 6, as a function of the logarithm of oxygen partial pressure. The dissolved form of tellurium into the slags in copper alloy-slag system can be determined from the slopes of the trend lines.

$L_{\text {Cu-matte or alloy/slag }} T e=\frac{\text { wt }-\% \text { Te in Cu-matte or Cu-alloy }}{\mathrm{wt}-\% \text { Te in slag }}$

Based on the slope (black line in Fig. 6) [23, 25], tellurium dissolved into the slag as $\mathrm{TeO}$ in oxidizing conditions of secondary copper smelting, i.e. above $10^{-2} \mathrm{~Pa}$ oxygen partial pressure. In more reducing conditions, tellurium seemed to dissolve as elemental species. This conclusion regarding dissolution as neutral, elemental species should

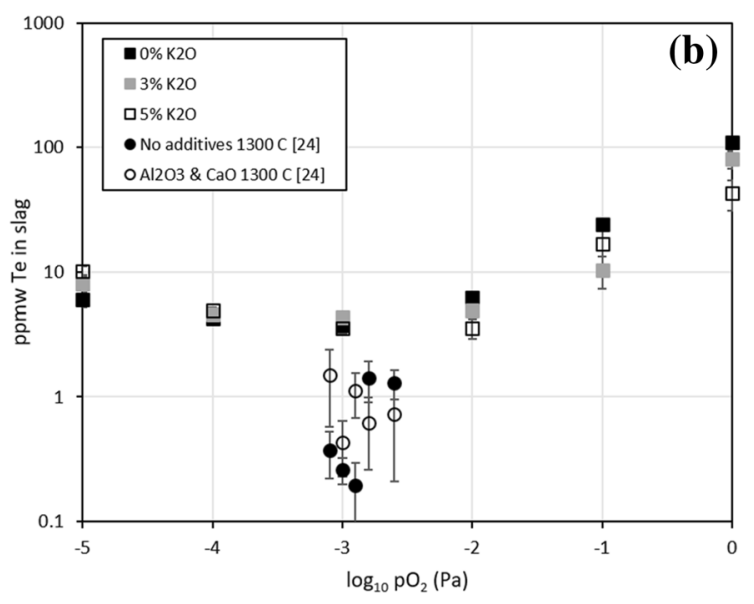

trations of tellurium in matte-slag system, adopted from Sukhomlinov et al. [24], are shown for comparison 


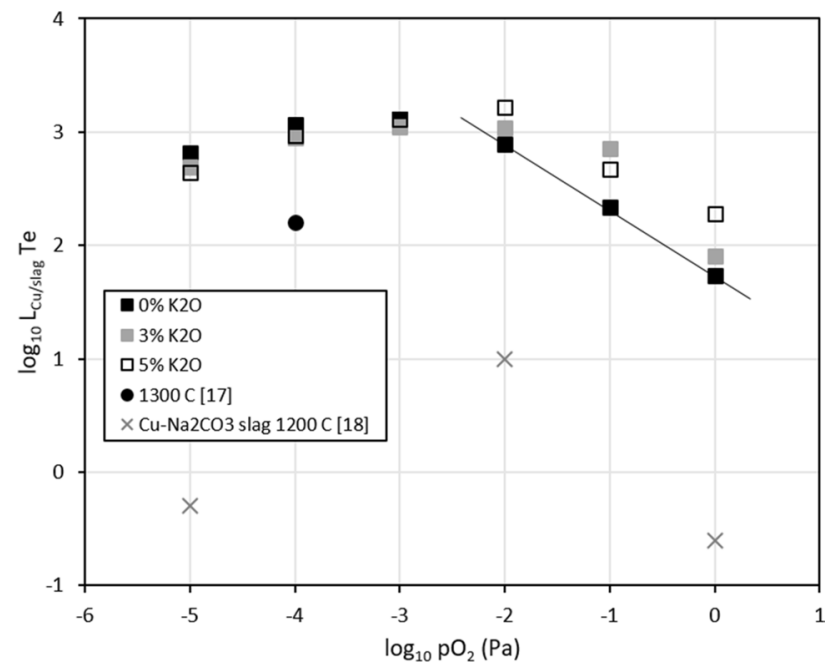

Fig. 6 Distribution coefficient of tellurium between copper alloy and different slags. Results from two earlier studies $[17,18]$ have also been plotted for comparison

be reliable in the sense that the concentrations of tellurium in ISA slags and copper alloy in all experimental conditions were well above the detection limits of LA-ICP-MS and EPMA, respectively. Thus, the calculated distribution coefficient values represent actual coefficients, not minimum ones, such as reported by us for platinum, for example [34]. In oxidizing conditions, $5 \mathrm{wt} \%$ potassium oxide in the slag notably increased the deportment of tellurium into the copper alloy, where it can be recovered in later process stages by anode slime treatment. This suggests that the dissolution mechanism of tellurium in iron silicate slags is related to the fraction of non-bridging oxygen ions.

Kojo et al. [18] studied the thermodynamics of tellurium removal from liquid copper by sodium carbonate slags. They found a maximum in the distribution coefficient of tellurium at $\mathrm{pO}_{2} 10^{-2} \mathrm{~Pa}$. Based on our results, it is also possible that the distribution coefficient starts to exhibit a slight downward trend in more reducing conditions, thus corresponding roughly to the behavior reported by Kojo et al. at $1200^{\circ} \mathrm{C}$, even though their values are two or three orders of magnitude lower than ours. The results of Kojo et al. and the distribution coefficient value obtained by Johnston et al. [17] at $10^{-4} \mathrm{~Pa}$ oxygen partial pressure and $1300^{\circ} \mathrm{C}$, between metallic copper and fayalite slag, have been marked in Fig. 6 for comparison with our results.

In primary copper smelting conditions, the dependence of the distribution coefficient on the oxygen partial pressure was much stronger than in the secondary smelting system, according to new data by Sukhomlinov et al. [24]. The trend, as a function of increasing oxygen partial pressure, i.e. increasing matte grade, was opposite compared to the metallic copper-slag results. Similar trends, although with lower slopes, have been reported before for PM's and PGM's in matte-slag systems by Avarmaa et al. [35]. The deportment of tellurium into the copper matte phase increased drastically as the matte grade (and oxygen partial pressure) increased. The addition of alumina and lime clearly decreased the deportment of tellurium into the copper matte. Avarmaa et al. [35] and Sukhomlinov et al. [24] have discussed the possible reasons for the increasing trends in distribution coefficient values as a function of increasing matte grade, attributing them to the properties of the copper matte as its sulfur-to-metal stoichiometry changes. The feature of selenium dissolution mechanism in slags as an intermetallic was also discussed recently by Sukhomlinov et al. [36].

Choi and Cho [16] studied earlier the behavior of tellurium in argon (and $\mathrm{CO}-\mathrm{CO}_{2}$ ) atmospheres $\left(\mathrm{pSO}_{2} \approx 0\right.$ ), through a wide (15-75 wt\%) matte grade range with $\mathrm{Ni}-\mathrm{Cu}$ mattes $(\mathrm{Ni} / \mathrm{Cu}=2)$ at $1250-1300{ }^{\circ} \mathrm{C}$, using different slag additives. According to their findings, the distribution coefficient of tellurium was not very strongly dependent on the $\mathrm{Ni}+\mathrm{Cu}$ concentration of the mattes investigated. The addition of basic oxides slightly increased the value of the distribution coefficient with all matte grades. All the aforementioned results have been plotted in Fig. 7. The differences between the results of Sukhomlinov et al. and Choi and Cho may be explained by the fact that the latter did not control the partial pressure of sulfur, and that their mattes contained more nickel than copper. The comparison with metallic copper-slag results presented in Fig. 6 is not straightforward due to the different $x$-axes, but in both cases, the smelting process can be considered moving forward in the chain of unit processes as the values on the $x$-axis increase.

\section{Conclusions}

As the generation of WEEE is increasing rapidly in the world, considerable efforts are being made to improve the recycling and recovery rates of different metals within. This study contributes to these efforts by determining the distribution behavior of tellurium, a common trace element in primary copper ores as well as electronic scrap, in secondary copper smelting conditions. An advanced equilibration-quenching-direct phase analyses technique was utilized, providing the true chemical solubilities of tellurium in each phase. The effect of potassium oxide on the slag boundaries was also discussed in relation to the MTOX database of MTDATA software. 


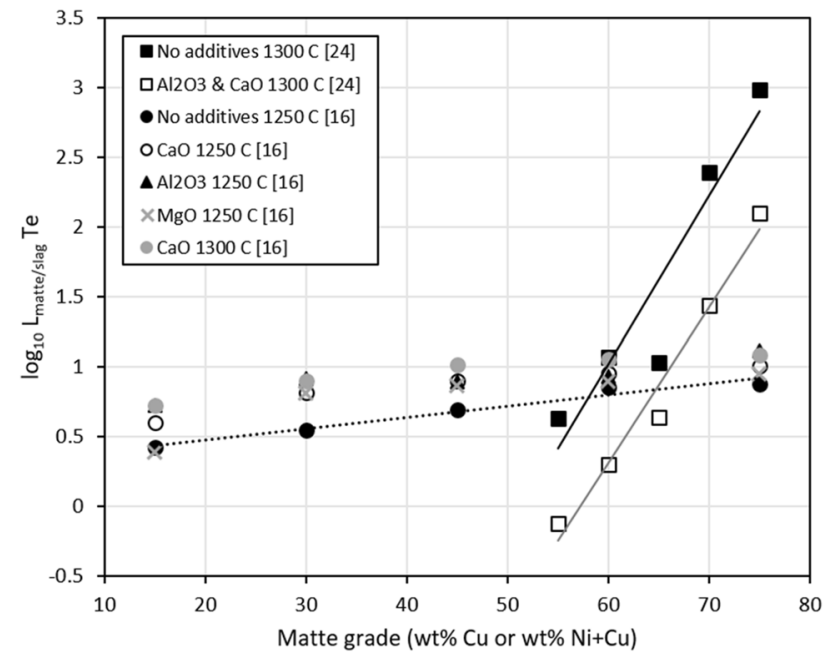

Fig. 7 Comparison of tellurium distribution coefficients between matte and slag in different studies. In the results of Sukhomlinov et al. [24], the 55 wt\% Cu matte grade corresponds to an oxygen partial pressure of $10^{-3.1} \mathrm{~Pa}$, and the $75 \mathrm{wt} \% \mathrm{Cu}$ matte grade to $10^{-2.6} \mathrm{~Pa}$, while $\mathrm{pSO}_{2}$ was fixed to $10^{4} \mathrm{~Pa}$. The data by Choi and Cho [16] were from argon gas atmosphere

According to our experimental results, the MTOX database exaggerates the equilibrium solubility of alumina in the slags investigated, as well as the effect of potassium oxide on the slag boundaries. More experimental data is required in order to optimize the database for alumina and $\mathrm{K}_{2} \mathrm{O}$-containing slags.

The concentration of tellurium in copper alloy was more than 50 times higher than in the slags in oxidizing smelting conditions, and more than 1000 times higher in reducing conditions. The addition of up to $5 \mathrm{wt} \% \mathrm{~K}_{2} \mathrm{O}$ into the iron-aluminous spinel-saturated iron silicate slag increased the distribution coefficient in oxidizing conditions, thus improving tellurium deportment into the copper phase, where it can be recovered in later process stages, most commonly from anode slimes after electrolytic refining.

The vaporization of tellurium was far less significant in our experiments simulating secondary copper smelting than in recent data obtained from laboratory scale primary copper smelting experiments, and overall the recovery possibilities seem to be greater in secondary copper smelting. The results presented in this article are important for building better process models and optimizing process parameters for different feed material compositions in industrial operations.
Acknowledgements Open access funding provided by Aalto University. L.K. acknowledges the research grant from Finnish Steel and Metal Producers' Fund. The contribution of Mr. Lassi Pakkanen at Geological Survey of Finland regarding the EPMA analyses is greatly appreciated. This study utilized the Academy of Finland's RawMatTERS Finland Infrastructure (RAMI) based jointly at Aalto University, VTT and GTK in Espoo, Finland.

\section{Compliance with ethical standards}

Conflict of interest The authors declare that they have no conflict of interest.

Open Access This article is licensed under a Creative Commons Attribution 4.0 International License, which permits use, sharing, adaptation, distribution and reproduction in any medium or format, as long as you give appropriate credit to the original author(s) and the source, provide a link to the Creative Commons licence, and indicate if changes were made. The images or other third party material in this article are included in the article's Creative Commons licence, unless indicated otherwise in a credit line to the material. If material is not included in the article's Creative Commons licence and your intended use is not permitted by statutory regulation or exceeds the permitted use, you will need to obtain permission directly from the copyright holder. To view a copy of this licence, visit http://creativecommons .org/licenses/by/4.0/.

\section{Appendix}

See Fig. 8.

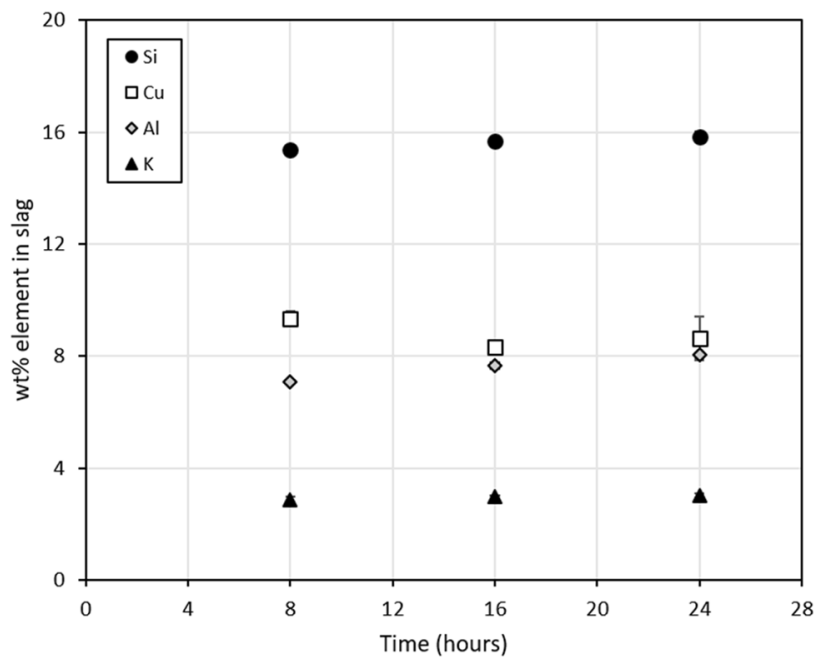

Fig. 8 Concentrations of elements in slag as a function of time at $10^{-1} \mathrm{~Pa}$ oxygen partial pressure. Based on the results, $16 \mathrm{~h}$ was deduced to be enough time for equilibration 


\section{References}

1. George MW (2003) Selenium and tellurium. U.S. Geological Survey, Minerals Yearbook 2003, pp 65.1-65.8

2. Makuei FM, Senanayake G (2018) Extraction of tellurium from lead and copper bearing feed materials and interim metallurgical products-a short review. Miner Eng 115:79-87

3. Schuyler Anderson C (2019) Tellurium. U.S. Geological Survey, Mineral Commodity Summaries, pp 166-167. ISBN: 978-1-4113-4283-5

4. Kusch S, Alsheyab M (2017) Waste electrical and electronic equipment (WEEE): a closer look at photovoltaic panels. In: Proceedings of the 17th international multidisciplinary scientific geoconference SGEM 2017, 29 June-5 July 2017, vol 17(41), pp 317-324

5. BIO Intelligence Service (2011) Study on photovoltaic panels supplementing the impact assessment for the recast of the WEEE directive, Paris, France. https://op.europa.eu/en/publi cation-detail/-/publication/944769fa-6545-41c1-8d1f-de5f2 061c3c0. Accessed 20 Jan 2020

6. Goldfarb R (2014) Tellurium: the bright future of solar energy. USGS Mineral Resources Program Fact Sheet. https://doi. org/10.3133/fs20143077

7. Zhang X, Jiao S, Tu J, Song W-L, Xiao X, Li S, Wang M, Lei H, Tian $D$, Chen H, Fang D (2019) Rechargeable ultrahigh-capacity tellurium-aluminum batteries. Energy Environ Sci 12(6):1918-1927

8. Li H, Wang K, Zhou H, Guo X, Cheng S, Jiang K (2018) Telluriumtin based electrodes enabling liquid metal batteries for high specific energy storage applications. Energy Storage Mater 14:267-271

9. Koketsu T, Paul B, Wu C, Kraehnert R, Huang Y, Strasser P (2016) A lithium-tellurium rechargeable battery with exceptional cycling stability. J Appl Electrochem 46:627-633

10. Li Y, Wang M-Q, Chen Y, Hu L, Liu T, Bao S, Xu M (2018) Musclelike electrode design for Li-Te batteries. Energy Storage Mater 10:10-15

11. Brenan JM (2018) Se-Te fractionation by sulfide-silicate melt partitioning: implications for the composition of mantle-derived magmas and their melting residues. Earth Planet. Sci. Lett. 422:45-57

12. Avarmaa $\mathrm{K}, \mathrm{O}$ 'Brien $\mathrm{H}$, Valkama $\mathrm{M}$, Klemettinen $\mathrm{L}$, Niemi $\mathrm{E}$, Taskinen $\mathrm{P}$ (2018) Properties of $\mathrm{Na}_{2} \mathrm{O}-\mathrm{SiO}_{2}$ slags in Doré smelting. Miner Process Extr Metall Rev 39(2):125-135

13. Swinbourne DR, Barbante GG, Sheeran A (1998) Tellurium distribution in copper anode slimes smelting. Metall Mater Trans B 29B:555-562

14. Johnson EA, Oden LL, Sanker PE, Fulton RL (1984) Minor-element interactions in copper matte smelting. Report of investigations. United States Department of the Interior, Bureau of Mines; 8874

15. Johnson EA, Sanker PE, Oden LL, See JB (1982) Copper losses and the distribution of impurity elements between matte and silica-saturated iron silicate slags at $1,250^{\circ} \mathrm{C}$. Report of investigations. United States Department of the Interior, Bureau of Mines; 8655

16. Choi N, Cho WD (1997) Distribution behavior of cobalt, selenium, and tellurium between nickel-copper-iron matte and silica-saturated iron silicate slag. Metall Mater Trans B 28B:429-438

17. Johnston MD, Jahanshahi S, Zhang L, Lincoln FJ (2010) Effect of slag basicity on phase equilibria and selenium and tellurium distribution in magnesia-saturated calcium iron silicate slags. Metall Mater Trans B 41B:625-635

18. Kojo I, Taskinen P, Lilius K (1985) Thermodynamics of removing selenium and tellurium from liquid copper by sodium carbonate slags. Metall Trans B 16B:171-172
19. Schlitt WJ, Richards KJ (1973) The behavior of selenium and tellurium in metal-matte systems. Metall Trans 4:819-825

20. Chen C, Zhang L, Wright S, Jahanshahi S (2006) Thermodynamic modelling of minor elements in copper smelting processes. In: Sohn international symposium on advanced processing of metals and materials, vol 1. Thermo and physicochemical principles: non-ferrous high-temperature processing, California, USA.TMS, pp 335-348. ISBN: 978-0-87339-634-9

21. Chen C, Zhang L, Jahanshahi S (2013) Application of MPE model to direct-to-blister flash smelting and deportment of minor elements. In: Proceedings of copper 2013, Santiago, Chile, pp 857-871

22. Gisby J, Taskinen P, Pihlasalo J, Li Z, Tyrer M, Pearce J, Avarmaa K, Björklund P, Davies H, Korpi M, Martin S, Pesonen L, Robinson J (2017) MTDATA and the prediction of phase equilibria in oxide systems: 30 years of industrial collaboration. Metall Mater Trans B 48(1):91-98

23. Klemettinen $\mathrm{L}$, Avarmaa $\mathrm{K}, \mathrm{O}$ 'Brien $\mathrm{H}$, Taskinen $\mathrm{P}$, Jokilaakso $\mathrm{A}$ (2019) Behavior of tin and antimony in secondary copper smelting process. Minerals 9(1):39

24. Sukhomlinov $D$, Klemettinen $L$, $O$ 'Brien $H$, Taskinen $P$, Jokilaakso A (2019) Behavior of Ga, In, Sn, and Te in copper matte smelting. Metall Mater Trans B 50:2723-2732

25. Klemettinen L, Avarmaa K, Taskinen P, Jokilaakso A (2018) Behavior of nickel as a trace element and time-dependent formation of spinels in WEEE smelting. In: Proceedings of extraction 2018 , Ottawa, ON, Canada. Springer, Cham, pp 1073-1082

26. Pouchou JL, Pichoir F (1986) Basic expression of "PAP" computation for quantitative EPMA. In: 11th international congress on X-ray optics and microanalysis ICXOM, Canada, pp 249-256

27. Jochum KP, Weis U, Stoll B, Kuzmin D, Yang Q, Raczek I, Jacob DE, Stracke A, Birbaum K, Frick DA, Günther D, Enzweiler J (2011) Determination of reference values for NIST SRM 610-617 glasses following ISO guidelines. Geostand Geoanal Res 35(4):397-429

28. van Achterberg E, Ryan C, Jackson SE, Griffin WL (2001) Data reduction software for LA-ICP-MS. Laser ablation ICP-MS in the earth sciences - principles and applications. Mineralogical association of Canada, short course series (29), St John, pp 239-243

29. Volodin VN, Trebukhov SA, Kenzhaliyev BK, Nitsenko AV, Burabaeva NM (2018) Melt-vapor phase diagram of the Te-S system. Russ J Phys Chem A 92(3):407-410

30. Ohno R (1976) Rates of evaporation of silver, lead, and bismuth from copper alloys in vacuum induction melting. Metall Trans $B$ 7B(6):647-653

31. Gallois B, Lupis CHP (1981) Effect of oxygen on the surface tension of liquid copper. Metall Trans B 12B:549-557

32. Nexhip C, Davidson R, Sun S (2004) Surface tension of $\mathrm{Cu}-\mathrm{O}$ alloys at $1400 \mathrm{~K}$. In: VII international conference on molten slags fluxes and salts, Cape Town, South Africa. SA IMM, pp 271-276

33. Hino M, Itagaki K (2013) Measurements of activity of metalloid elements in nonferrous metallurgical systems. J MMIJ 129:51-58

34. Avarmaa K, Klemettinen L, O'Brien H, Taskinen P (2019) Urban mining of precious metals via oxidizing copper smelting. Miner Eng 133:95-102

35. Avarmaa K, O'Brien $\mathrm{H}$, Johto $\mathrm{H}$, Taskinen $\mathrm{P}$ (2015) Equilibrium distribution of precious metals between slag and copper matte at 1250-1350 C. J Sustain Metall 1:216-228

36. Sukhomlinov $D$, Klemettinen $L$, Virtanen $O$, Lahaye $Y$, Latostenmaa P, Jokilaakso A, Taskinen P (2020) Trace element distributions between matte and slag in direct nickel matte smelting. Can Metall Q. https://doi.org/10.1080/00084433.2019.1710386

Publisher's Note Springer Nature remains neutral with regard to jurisdictional claims in published maps and institutional affiliations. 